\title{
Support of bacterioplankton production by dissolved humic substances from three marine environments
}

\author{
Mary Ann Moran, Robert E. Hodson \\ Department of Marine Sciences, University of Georgia, Athens, Georgia 30602-2206, USA
}

\begin{abstract}
Dissolved humic substances from 3 marine environments with varying vascular plant influence were shown to contain biologically labile components. Biomass of marine bacterioplankton increased in grazer-free incubations in the presence of humic substance supplements equivalent to 2 -fold and 5-fold natural concentrations. Humic substances were present in highest concentration in seawater collected from a mangrove swamp site these humics had the highest vascular plant influence (estimated at $66 \%$ based on lignin phenol analysis) and yielded the least bacterial growth on a carbon basis. From 3 to $11 \%$ of the humic substances from all 3 sites were utilized by marine bacterioplankton over a $5 \mathrm{~d}$ period. Results of this study suggest that some fraction of the humic substances pool can have a relatively short turnover time in seawater, and point out the importance of identifying which specific components of the dissolved organic carbon pool are available for supporting marine bacterioplankton production.
\end{abstract}

KEY WORDS: Humic substances - Bacterioplankton - Seawater - Mangrove swamp - DOC

\section{INTRODUCTION}

Views of the biological role of humic substances in aquatic environments have changed significantly over the past $5 \mathrm{yr}$, from that of biologically inert compounds of little trophodynamic importance to that of potentially important carbon and energy sources for bacteria, and ultimately for microbial food webs (Hessen et al. 1990, Jones 1992). The earlier notion that humic substances are biologically unimportant derived from their complex structure, chemical heterogeneity and likely origin as refractory remains or condensates from the decomposition of plant and animal biomass. Yet recent studies employing experimental approaches have demonstrated an important biological role for humic substances as substrates for the growth of natural bacterial assemblages in a variety of aquatic environments, including lakes (Tranvik \& Höfle 1987, Moran \& Hodson 1990), freshwater wetlands (Moran \& Hodson 1990) and rivers (Clair et al. 1989, Leff \& Meyer 1991).

Resolution of the apparent conflict between the refractory chemical structure of humic substances and their demonstrated biological importance might be found in the following 2 considerations. First, the size of the humic substances pool in most aquatic environments is large, perhaps 3000 -fold larger than that of any individual readily assimilable compound (e.g. dissolved simple sugars and amino acids) which have been the primary focus of bacterial assimilation studies. In essence, because of its sheer size, this large heterogeneous pool of relatively refractory compounds may compete in importance as a bacterial substrate with the smaller pools of labile compounds. Second, the breakdown of aquatic humic substances may occur by way of a synergism between biological and photochemical processes. Recent studies have shown that photooxidation converts dissolved humic substances into biologically available compounds, either through the formation of nonhumic, small molecular weight molecules from the humic substances (Kieber et al. 1989, 1990), or perhaps through chemical modifications of core humic materials (Geller 1986, Mopper et al. 1991). Photochemical processes may therefore gradually modify the chemical structure of the humic 
substances, continually converting some portion of the humic $\mathrm{C}$ pool into compounds more readily available to bacteria.

While bacterial growth on dissolved humic substances has now been demonstrated for a number of freshwater environments, little is known about the biological availability of marine humic substances. In this study, we quantify bacterial growth on humic substances collected from 3 marine environments: a Bahamian mangrove swamp, a nearshore site adjacent to the mangrove swamp, and the Gulf Stream between Miami, Florida, USA, and the Bahamas.

\section{METHODS}

Humic substance isolation. Water samples were collected during a cruise aboard the RV 'Gyre' on October 12 and 13, 1992. Sample GS was collected in the Gulf Stream at $25^{\circ} 48^{\prime} \mathrm{N}$ and $79^{\circ} 50.5^{\prime} \mathrm{W}$, between Miami, Florida, and the Bahamas. Two other samples were collected in the vicinity of Crab Cay, the Bahamas $\left(25^{\circ} 26^{\prime} \mathrm{N}, 77^{\circ} 54^{\prime} \mathrm{W}\right)$; sample MS was collected at low tide in a mangrove swamp creek in the interior of the island, and sample NS was collected at low tide from the nearshore area of Crab Cay (1 km offshore). The samples were collected within weeks of the occurrence of a major hurricane (Hurricane Andrew), which left some of the mangrove trees at the MS site dead and most almost completely defoliated.

To obtain humic substances for chemical analysis, surface water samples (801 for GS, 601 for MS and NS) were collected in Nalgene carboys and sequentially filtered though a Gelman A/E prefilter and a Whatman GF/F filter using a $293 \mathrm{~mm}$ diameter plexiglass filter holder. Filtered water was acidified to $\mathrm{pH} 2.0$ with $6 \mathrm{~N}$ $\mathrm{HCl}$. Two $40 \mathrm{ml}$ subsamples were removed from each water sample and placed in combusted glass vials with teflon-lined lids; these were stored at $4{ }^{\circ} \mathrm{C}$ for later determination of dissolved organic carbon (DOC) concentration by high temperature combustion using a Shimadzu TOC-5000. The water samples were then pumped at a rate of $50 \mathrm{ml} \mathrm{min}^{-1}$ through $2.2 \times 40 \mathrm{~cm}$ columns of Amberlite XAD- 8 resin which had been previously cleaned with ether, acetonitrile and methanol, and rinsed with $\mathrm{HCl}, \mathrm{NaOH}$ and distilled/ deionized water (Aiken 1985). Samples of water from the column effluent were collected as described above for later determination of DOC concentration. The columns containing adsorbed humics were stored at $4^{\circ} \mathrm{C}$, and following the cruise, humics were eluted from the resin with $0.1 \mathrm{~N} \mathrm{NaOH}$ followed by a distilled water rinse. The humic eluants were deionized by passage through $2.2 \times 40 \mathrm{~cm}$ columns of Bio Rad AG-MP50 cation exchange resin. Humic substances were concentrated from the eluants by rotary evaporation followed by freeze drying, and dried material was stored frozen until chemical analysis.

To obtain humic substances for biological studies, an additional 20 l sample was collected at each site and filtered, acidified, and passed though an XAD- 8 resin as described above. For these samples, the humic substances were eluted from the column and deionized onboard ship to provide a 40 -fold concentrate $(500 \mathrm{ml}$ final volume) of humic substances from each site.

Although the XAD-8 and ion exchange resins were extracted with solvents and washed extensively prior to use, a small amount of organic matter may nonetheless bleed from the resin (Aiken 1988). This caused concern with regard to the possible contamination of isolated humic substances with biologically-available carbon from the resin. To control for any effects of resin contamination, $20 \mathrm{l}$ (for biological studies) and $80 \mathrm{l}$ (for chemical analysis) samples of purified water (Nanopure system) were acidified, filtered and passed through XAD-8 and ion exchange columns just as described for the seawater samples.

Bacterioplankton growth studies. Surface water from the GS station was filtered through a $0.6 \mu \mathrm{m}$ poresize Nuclepore filter to remove bacterivores and placed in $1 \mathrm{l}$ acid-washed flasks. Flasks were then supplemented with humic substance concentrates equivalent to 2 -fold $(2 \times)$ and 5 -fold $(5 x)$ the natural humic substance concentration at each site. For $2 \times$ studies, 3 replicate flasks of each of 4 treatments (MS, NS, GS and control 'humics' prepared from Nanopure water) received $570 \mathrm{ml}$ filtered seawater and $30 \mathrm{ml}$ humic concentrate. For $5 \times$ studies, flasks received $525 \mathrm{ml}$ filtered seawater and $75 \mathrm{ml}$ humic concentrate. Two $40 \mathrm{ml}$ subsamples were removed from each flask, filtered through a Whatman GF/F filter in a combusted glass filtration unit, and collected in combusted glass vials with teflon-lined caps. Subsamples were acidified with $20 \mu$ l of $50 \%$ phosphoric acid and stored at $4{ }^{\circ} \mathrm{C}$ until later determination of DOC concentration.

The 24 flasks were shaken at 100 rpm in the dark at room temperature for $5 \mathrm{~d}$, and net change in bacterioplankton biomass was followed in each flask. At the initiation of the experiment (Day 0) and at Days 3, 4 and 5, a $10 \mathrm{ml}$ subsample was removed from each flask using a combusted glass pipette. Subsamples were placed in plastic scintillation vials containing $0.6 \mathrm{ml}$ buffered formalin ( $2 \%$ final concentration of formaldehyde) and stored refrigerated. For determination of bacterial biomass, 3 to $7 \mathrm{ml}$ of preserved sample was filtered through a $0.2 \mu \mathrm{m}$ pore-size blackened Poretics membrane filter. A $1 \mathrm{ml}$ aliquot of $0.01 \%$ acridine orange was placed on top of the filter, and after 3 min of staining, the acridine orange solution was removed by vacuum filtration. The filters were viewed with an Olympus BH-2 epifluores- 
cence microscope attached to a Microcomp image analysis system. Ten fields from each filter were analyzed for bacterial cell number and volume. For volume determinations, the area and perimeter of each cell was recorded by the image analysis system, and these parameters were converted to widths and lengths (Fry 1988) and then to volumes (Moran \& Hodson 1990). We sized an average of 180 cells from each flask at each time point. Total bacterial biovolume $\left(\mu \mathrm{m}^{3} \mathrm{ml}^{-1}\right)$ was calculated by multiplying the average number of bacterial cells per milliliter by the average volume of the cells.

In a second study, six $125 \mathrm{ml}$ acid-washed flasks received $60 \mathrm{ml}$ filter-sterilized artificial seawater (Sigma sea salts), nutrient supplements ( $1 \mu \mathrm{M} \mathrm{P}$ and $5 \mu \mathrm{M} \mathrm{N}$ as ammonia and nitrate), and a bacterial inoculum obtained by concentrating cells from $0.6 \mu \mathrm{m}$ seawater filtrates over $0.2 \mu \mathrm{m}$ pore-size Nuclepore filters. Half the flasks were amended with humic substances equivalent to $250 \mu \mathrm{M} \mathrm{C}$ and half were amended with distilled water (control flasks). Flasks were gently shaken in the dark at room temperature. Subsamples were removed for direct counts of bacterial cells at the beginning and end (Day 4) of the experiment according to procedures described above. Cell volumes were not measured in this experiment.

Humic substance characterization. Carbon, nitrogen, and hydrogen content of the freeze-dried humic substances was determined on a Perkin-Elmer $240 \mathrm{C}$ CHN analyzer. Lignin-derived phenols were quantified by gas chromatographic analysis of cupric oxide oxidation products of humic substances (Hedges \& Ertel 1982, Ertel et al. 1984). The oxidation procedure involved reacting 5 to $10 \mathrm{mg}$ freeze-dried humic substances with alkaline cupric oxide for $3 \mathrm{~h}$ at $170^{\circ} \mathrm{C}$ to produce 3 characteristic lignin-derived phenols: vanillic acid, vanillin and acetovanillone. The lignin phenols were extracted from the oxidation mixture with ether and converted to trimethylsilyl derivatives, and their quantification was carried out on an HP 5890 gas chromatograph. Samples were analyzed both on Altech SE-30 (100\% dimethyl polysiloxane) and J\&W DB-1701 (86\% dimethyl and $14 \%$ cyanopropylphenyl polysiloxane) silica capillary columns (Hedges et al. 1988, Moran et al. 1991a). Corrections for coeluting compounds were made after normalizing to vanillic acid concentrations. Previous checks on the reproducibility of the oxidation procedure and gas chromatographic analysis indicated that duplicate samples did not differ in measured lignin phenol content by more than $17 \%$ (Moran et al. 1991b).

Mangrove-derived humic substance characterization. Senescing mangrove leaves were collected from Crab Cay in October 1989 . Leaves were dried at $50^{\circ} \mathrm{C}$ and ground to $<425 \mu \mathrm{m}$. Three grams of leaf material were placed in 11 flasks containing artificial seawater amended with inorganic nutrients $(5 \mu \mathrm{M} N$ and $1 \mu \mathrm{M} P)$ and a bacterial inoculum. At 2, 4 and 8 wk, 3 replicate flasks were harvested. Dissolved humic substances were isolated and oxidized with cupric oxide for lignin phenol analysis as described above.

\section{RESULTS}

DOC concentrations in seawater from the 3 sites were 483 (MS), 192 (NS) and 208 (GS) $\mu \mathrm{M} \mathrm{C}$, while humic substances concentrations were 117 (MS), 25 (NS) and 25 (GS) $\mu \mathrm{M} \mathrm{C}$. Humic substances therefore accounted for $24 \%$ (MS), $13 \%$ (NS) and $12 \%$ (GS) of the total DOC at these sites. In our previous collections of seawater in the Crab Cay system (Moran et al. $1991 \mathrm{~b}$ ), humics accounted for an average of $21 \%$ (MS site, $n=5$ ) and $13 \%$ (NS site, $n=4$ ) of the bulk DOC.

Chemical analysis of the isolated humic substances showed a higher $\mathrm{C}: \mathrm{N}$ ratio in humics from the mangrove system relative to the 2 planktonic marine sites (Table 1). Humic substance $\mathrm{H}: \mathrm{C}$ ratios were similar among the sites. Lignin phenol analysis provided a mechanism for characterizing the importance of vascular plants as a source material for humic substances, since lignin is unique to vascular plant structural material. Lignin phenols had the highest concentration in humic substances from the MS site $(0.59 \%$ of humic $\mathrm{C})$, were intermediate in concentration at the GS site $(0.30 \%)$ and lowest at the NS site $(0.21 \%)$. We estimated the percent of humics derived from vascular plant sources by comparing the quantity of lignin phenols in humic substances from the 3 sites with that from a vascular plant end member, in this case humics formed during the degradation of mangrove leaves in a laboratory microcosm. Mangrove leaf-derived humic $\mathrm{C}$ contained $0.89 \%$ lignin phenols (average of samples collected after 2, 4 and 8 wk of decomposition) (Moran et al. 1991b). We used the equation

$\%$ vascular plant-derived humics $=\left(\% \mathrm{LP}_{\text {site }} / \% \mathrm{LP}_{\operatorname{man}}\right) \times 100$ where $\% \mathrm{LP}_{\text {ste }}$ is the percent lignin phenols in humic $\mathrm{C}$ from a site and \%LP $P_{\operatorname{man}}$ is the percent lignin phenols in humic $\mathrm{C}$ from mangrove leaf-derived DOC.

Table 1. Chemical characteristics of humic substances from 3 marine environments near the Bahamas. MS: mangrove swamp; NS: nearshore site; GS: Gulf Stream

\begin{tabular}{|ccccc|}
\hline Site & $\begin{array}{r}\text { C:N } \\
\text { ratio }\end{array}$ & $\begin{array}{c}\text { H:C } \\
\text { ratio }\end{array}$ & $\begin{array}{c}\text { Lignin phenols } \\
\left(\mu^{-1} \mathrm{mg}^{-1} \text { humic C) }\right.\end{array}$ & $\begin{array}{c}\text { Vascular plant } \\
\text { influence (\%) }\end{array}$ \\
\hline MS & 22.3 & 0.10 & 9.43 & 66 \\
NS & 13.4 & 0.11 & 3.34 & 24 \\
GS & 14.4 & 0.12 & 4.70 & 36 \\
\hline
\end{tabular}


By this method, we calculated the vascular plant influence to be $66 \%$ for MS humics, $24 \%$ for NS humics and $36 \%$ for GS humics. Vascular plant influence on humic substances from the MS site collected 3 yr previously was determined to be $63 \%$ (calculated from data in Moran et al. 1991b), a value similar to the one obtained in the present study. Likewise, for the NS site, the value estimated here is similar to results of our previous work (21\%; Moran et al. 1991b). For the GS site, however, the value from this study is much higher than that found earlier for Gulf Stream water $<1 \%$; Moran et al. 1991a). The stronger vascular plant influence on the humic substances from the GS site may be the result of major disruptions from Hurricane Andrew to coastal and terrestrial ecosystems in the Caribbean and southeastern U.S. in the weeks preceding sample collection. Our estimate of the vascular plant contribution to GS humics is the least robust, however, since this calculation assumes that the source of lignin phenols in the GS sample is either mangrove detritus or other plant detritus with similar lignin content. For the MS and NS sites, mangroves are indeed the predominant vascular plant in the ecosystem and the most likely source of the lignin phenols.

In the first biological availability study, the magnitude of humic $\mathrm{C}$ additions to the filtered GS water varied among treatments, depending on the natural humic substance concentrations at each site. For the MS site, humic $C$ supplements amounted to $250(2 \times$ treatment) and $625(5 \times$ treatment) $\mu \mathrm{M} \mathrm{C}$, giving final concentrations of 433 and $808 \mu \mathrm{M} \mathrm{C}$. For the NS site, humic supplements of 75 and $175 \mu \mathrm{M} \mathrm{C}$ resulted in final concentrations of 292 and $400 \mu \mathrm{M}$ C. For the GS site, supplements of 75 and 192 resulted in final concentrations of 275 and $383 \mu \mathrm{M} \mathrm{C}$. In the incubations supplemented with control 'humics' (i.e. resin eluent from Nanopure water samples), the GS water was supplemented with $25(2 \times)$ and $58(5 \times) \mu \mathrm{M} \mathrm{C}$ i this carbon may have originated either from resin bleed, or from DOC present in low concentration in the purified water used to prepare the control humics (e.g. Benner \& Strom 1992), or both. If resin bleed was the source, this carbon was present in the humic supplements of the other treatments as well, and any effects on bacterial growth was accounted for by subtraction of control values. If purified water was the source, this carbon was not present in the other treatments, and, if biologically available, subtraction of control values from treatment values resulted in an underestimation of the growth of bacterioplankton on marine humic substances.

The bioassay approach taken in this study has been used previously to determine the availability of bulk DOC or specific fractions of DOC for assimilation by natural bacterial communities (Tranvik \& Höfle
1987, Moran \& Hodson 1990, Leff \& Meyer 1991). Because predation pressure by bacterivores was decreased substantially by $0.6 \mu \mathrm{m}$ pore-size filtration of GS seawater, growth at the expense of available DOC in the initial days of the bioassay was evident as an accumulation of bacterial biomass. After incubation for several days there was a decrease in bacterial biomass in some flasks. This may have been caused by the reestablishment of protozoan populations (although we did not observe protozoans during bacterial counting), or the effects of bacteriophage. Thus, the highest bacterial biovolume attained in the flasks was used as an index of the amount of biologically available DOC.

Results of the bioassay studies indicated that humic substances from all 3 sites supported measurable growth of marine bacterioplankton (Fig. 1). Increases in bacterial biomass in the control treatments (due to
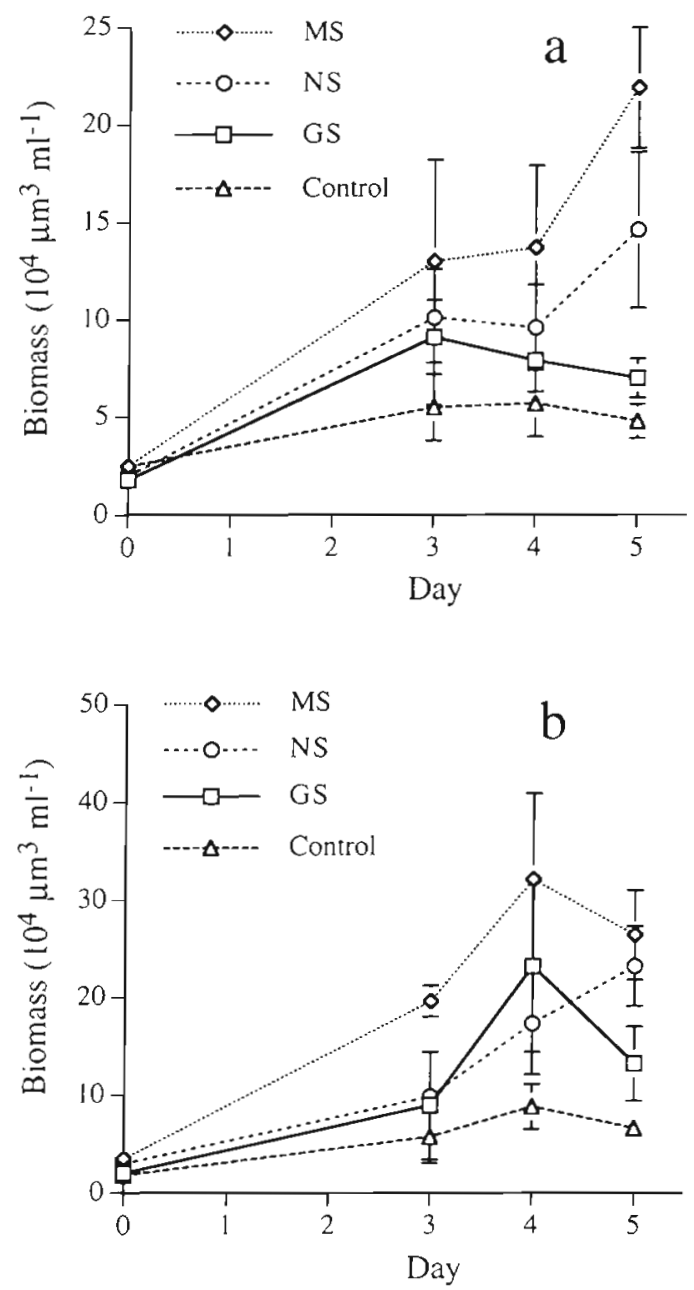

Fig. 1. Changes in bacterial biomass ( $\pm 1 \mathrm{SE}$ ) in $0.6 \mu \mathrm{m}$ filtered Gulf Stream (GS) seawater supplemented with (a) 2 -fold and (b) 5-fold ambient concentrations of humic substances from the 3 environments and from distilled water controls. MS: mangrove swamp; NS nearshore site 
biologically available DOC in the $0.6 \mu \mathrm{m}$ filtered GS water or in the supplements of control humics) were significantly lower than increases in GS water with additions of natural humic substances from any of the three sites. Biovolume increases were greatest for humic substance supplements from the MS site in both the $2 \times$ (Fig. 1a) and $5 \times$ (Fig. 1b) treatments, and were least for humic substance supplements from the GS site.

Because ambient humic substances concentrations, and therefore the amount of humic $\mathrm{C}$ added to flasks, differed between sites, we normalized the measured accumulation of bacterial biomass in each treatment to the carbon added. The increase in bacterial biomass above that measured in the control flasks (i.e. the growth due to humic substances alone) was divided by the amount of humic $\mathrm{C}$ added (Fig. 2). Humic substances from the mangrove swamp site (MS) were of poorest quality as a bacterial substrate, while humics from the nearshore site (NS) were of highest quality (ANOVA, $p=0.05$ ), supporting about twice the bacterial biomass per weight of humic $\mathrm{C}$ than the mangrove humics. Differences in bacterial growth may reflect differences in the biodegradability of the humic substances and/or differences in bacterial efficiency in utilization of the humic substances.

In the second biological availability study, artificial seawater was used as the medium rather than natural seawater to eliminate the possibility that observed bacterioplankton growth was due to added humic substances priming the utilization of nonhumic DOC. The number of bacterial cells in artificial seawater increased 11 -fold from the initial inoculum size in the presence of added humic substances, but less than 3 fold in the absence of humics (Table 2).

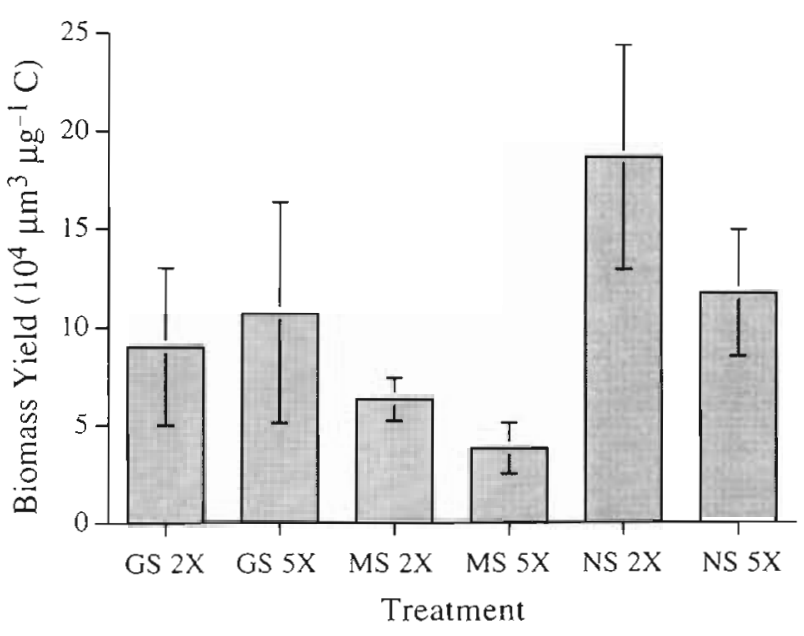

Fig. 2. Yield of bacterial biomass $( \pm 1 \mathrm{SE}$ ) from 2 concentrations $(2 x$ and $5 \times)$ of humic substances collected from the 3 marine environments (GS: Gulf Stream; MS: mangrove swamp; NS nearshore site). Data are corrected for growth in distilled water controls
Table 2. Bacterial cell numbers in artificial seawater supplemented with inorganic nutrients and $250 \mu \mathrm{M}$ humic $\mathrm{C}$

\begin{tabular}{|lrr|}
\hline Treatment & Day 0 & Day 4 \\
\hline Control & $1.07 \times 10^{5}$ & $3.04 \times 10^{5}$ \\
& $\left( \pm 2.7 \times 10^{2}\right)$ & $\left( \pm 2.3 \times 10^{3}\right)$ \\
Humic addition & $1.36 \times 10^{5}$ & $15.0 \times 10^{5}$ \\
& $\left( \pm 5.2 \times 10^{2}\right)$ & $\left( \pm 9.4 \times 10^{3}\right)$ \\
\hline
\end{tabular}

\section{DISCUSSION}

Our studies indicate that humic substances from marine environments support measurable secondary production of the marine bacterioplankton community. This conclusion is consistent with previous work in freshwater environments, where it also has been demonstrated that natural bacterial communities use dissolved humic substances as substrates for growth. Humic substances make up a smaller percentage of bulk DOC in marine environments ( 5 to $25 \%$ ) than in freshwater environments (40 to $80 \%$ ) (Thurman 1985). In order to increase our ability to detect bacterial growth at the expense of humics, therefore, Gulf Stream seawater was supplemented with humic substances at concentrations 2-and 5-fold ambient concentrations.

There was no evidence that increasing the total concentration of humic substances had any inhibitory effect on the growth of the bacterial populations. In the absence of inhibition, bacterial biomass accumulation at the expense of 2 -fold humic supplements should theoretically be $40 \%$ of the accumulation in 5 -fold supplements, after correction for controls. In our experiments, $2 \times$ incubations accumulated an average of $53 \%$ of the accumulation in the $5 \times$ incubations. Alternatively, in the absence of an inhibitory effect of concentration, bacterial biomass yield per weight of humic $C$ should be the same in the $2 \times$ and $5 \times$ incubations. Experimental results indicate no significant differences between yields at the 2 concentrations (Fig. 2), further suggesting that inhibition was not occurring.

Humic substances with significant vascular plant influence are found in terrestrial ecosystems (lakes, rivers, freshwater marshes) and in coastal marshes and mangroves where vascular plants dominate primary production. These terrestrial or coastal humic substances generally differ from humics formed in situ in planktonic marine environments in several ways, including a higher $C: N$ ratio, higher aromaticity (due primarily to the influence of lignin), and greater age (due to storage for varying times in soils or sediments prior to export to the ocean) (Hedges et al. 1986). These differences suggest that vascular plant-derived humic substances should be more biologically refractory than humics formed in oceanic systems, an as- 
sumption supported by our experimental results. MS humics had the highest vascular plant influence and the lowest apparent biological quality on a carbon basis, as calculated from the growth yield per weight of humic $C$, while NS humics had the lowest vascular plant influence and the highest quality. However, since only 3 to $11 \%$ of the humic substances were used by the bacterioplankton during the $5 \mathrm{~d}$ experiments

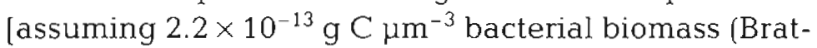
bak \& Dundas 1984) and a $30 \%$ average carbon conversion efficiency for the bacteria (Meyer et al. 1987, Tranvik \& Höfle 1987, Moran \& Hodson 1989)], we only have information on the biological availability of a small fraction of the humic $C$ pool. The remaining, and bulk of, the humic substances may or may not retain the site-specific differences in biological quality seen for the more available fraction.

For the GS site, the contribution of humic compounds relative to nonhumic compounds to the total measured bacterial growth can be calculated. Bacterial biomass accumulation in the control flasks averaged $7.3 \times 10^{4} \mu^{3} \mathrm{ml}^{-1}$; we assume for purposes of this calculation that most or all of this growth was at the expense of the natural DOC (both humic and nonhumic fractions) in the $0.6 \mu \mathrm{m}$ filtered GS seawater, rather than of any biologically available material added to the flasks with the control humics. Additional growth in the GS flasks supplemented with humic $C$ was $3.6 \times 10^{4} \mu^{3} \mathrm{ml}^{-1}$ for $2 \times$ incubations and $14.4 \times$

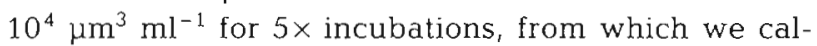
culate that growth at the expense of a $1 \times$ concentration of GS humics would be $2.4 \mu^{3} \mathrm{ml}^{-1}$ (mean of $2 \times$ and $5 \times$ values after normalization for $1 \times$ concentration). This value is $33 \%$ of the growth on whole seawater from the Gulf Stream, suggesting that humic substances are supporting about one-third of the total bacterial production in this water. This calculation applies only to batch cultures of GS seawater, however, since the relative importance of humic substances may be different in situ when DOC is being continually regenerated, especially since the pools of the more labile (primarily nonhumic) components will be the most rapidly depleted when regeneration of DOC is artificially stopped. This calculation also assumes that humic substances are utilized similarly regardless of concentration or the ratio of humic:nonhumic DOC and that the isolation procedure does not alter the biological availability of the humic substances.

To demonstrate that the additional bacterial growth observed in seawater supplemented with humics was in fact due to assimilation of humic substances, and not to stimulation by humics of assimilation of other components of the DOC pool, we measured growth of bacteria in an artificial seawater medium in which humics were the only available substrate (except for possible contaminants in the artificial sea salts). In this case, significant growth of bacteria was also observed, and final cell numbers were 5-fold greater that those measured in the control flasks.

Dissolved humic substances extracted from open seawater generally have been found to have little terrestrial (= vascular plant) influence. The $\mathrm{C}: \mathrm{N}$ ratios and stable isotope values of humics collected from ocean water suggest a primarily marine/planktonic origin (Williams \& Gordon 1970, Eadie at al. 1978), and lignin phenol concentrations indicate that only about $10 \%$ of marine humic substances have a terrestrial or coastal source (Meyers-Schulte \& Hedges 1986). Annual inputs of terrestrial and coastal humic substances to the ocean are high, however. Assuming $30 \%$ of the riverine DOC exported to the ocean is humic substances, approximately $6 \times 10^{13} \mathrm{~g}$ of humic C enters the marine environment annually from river sources alone (Meybeck 1982, Mantoura \& Woodward 1983). This amounts to an input of $0.05 \%$ of the terrestrially and coastally derived fraction of the marine humic substances pool (assuming the total marine DOC pool to be $1.2 \times 10^{18} \mathrm{~g} \mathrm{C}$, humic substances to be $10 \%$ of marine DOC, and terrestrial humics to be $10 \%$ of the marine humic substances pool). By these calculations, and assuming steady state concentrations, terrestrial and coastal humic substances would have a relatively rapid average turnover time (about $200 \mathrm{yr}$ ) in the ocean. By comparison, the bulk marine humics pool has been found by ${ }^{14} \mathrm{C}$ dating to have an average turnover time greater than 4500 yr (Bauer et al. 1992).

The reason for the discrepancy between the expected biological recalcitrance of vascular plantderived humic substances, on the one hand, and the small reservoir of terrestrially derived humics in the ocean, on the other, is not clear. One possibility is that biological processes may be more important than previously considered in the turnover of vascular plantrich humic substances in the sea. We demonstrate here that up to $11 \%$ of the humic substances collected from a coastal mangrove system are utilized by marine bacterioplankton within a few days. Previously, $24 \%$ of humic substances formed from degrading salt marsh grass Spartina alterniflora (Moran \& Hodson 1994) was found to be readily assimilated. Furthermore, recent observations of photochemical oxidation of humic substances (Kieber et al. 1990, Mopper et al. 1991) suggest a mechanism whereby photochemical processes may prime the biologically mediated degradation of humics. The higher aromaticity and color of terrestrial and coastal humic substances renders them particularly susceptible to absorption of UV light, and therefore may make them more photochemically reactive than other fractions of marine DOC. 
Unraveling the role of biological processes in the turnover of marine DOC is important for increasing our overall understanding of the biogeochemical cycling of carbon in the ocean. It is becoming clear that relegating certain classes of DOC to a 'refractory' category, which is then given up to the realm of geochemistry, is inappropriate, as components of even the most 'refractory' classes of DOC can indeed cycle at biologically relevant rates. Identifying which specific components of marine DOC are supporting bacterioplankton production, and their relative importance, is an important challenge for future work. Our results suggest that the DOC pool might best be conceptualized as a continuum of compounds varying in biological utilizability, as determined by chemical structure, susceptibility to photochemical modification, and environmental influences.

Acknowledgements. We thank Edward Sheppard for excellent technical assistance and Nasreen Bano for reviewing this manuscript. This research was funded by grant OCE9116450 from the National Science Foundation.

\section{LITERATURE CITED}

Aiken, G. (1985). Isolation and concentration techniques for aquatic humic substances. In; Aiken, G. R., McKnight, D. M., Wershaw, R. L., MacCarthy, P. (eds.) Humic substances in soil, sediment, and water. Wiley, Chichester, p. $363-385$

Aiken, G. R. (1988). A critical evaluation of the use of macroporus resins for the isolation of aquatic humic substances. In: Frimmel, F. H., Christman, R. F. (eds.) Humic substances and their role in the environment. Wiley, Chichester, p. 15-28

Bauer, J. E., Williams, P. M., Druffel, E. R. M. (1992). ${ }^{14} \mathrm{C}$ activity of dissolved organic carbon fractions in the northcentral Pacific and Sargasso Sea. Nature 357: 667-670

Benner, R., Strom, M. (1993). A critical evaluation of the analytical blank associated with DOC measurements by high-temperature catalytic oxidation. Mar. Chem. 41: $153-160$

Bratbak, G., Dundas, I. (1984). Bacterial dry matter content and biomass estimations. A.ppl. environ. Microbiol. 48: $755-757$

Clair, T A., Bärlocher, F., Brassard, P., Kramer, J. R. (1989). Chemical and microbial diagenesis of humic matter in freshwaters. Water Air Soil Pollut. 46: 205-211

Eadie, B. J., Jeffrey, L. M., Sackett, W. M. (1978). Some observations on the stable carbon isotope composition of dissolved and particulate organic carbon in the marine environment. Geochim. cosmochim. Acta 42: $1265-1269$

Ertel, J. R., Hedges, J. I., Perdue, E. M. (1984). Lignin signature of aquatic humic substances. Science 223: 485-487

Fry, J. C. (1988). Determination of biomass. In; Austin, B. (ed.) Methods in aquatic bacteriology. John Wiley and Sons, New York, p. 27-72

Geller, A. (1986). Comparison of mechanisms enhancing biodegradability of refractory lake water constituents. Limnol. Oceanogr. 31: 755-764

Hedges, J. I., Clark, W. A., Cowie, G. L. (1988). Organic matter sources to the water column and surficial sediments of a marine bay. Limnol. Oceanogr. 33: 1116-1136

Hedges, J. I., Ertel, J. R. (1982). Characterization of lignin by gas capillary chromatography of cupric oxide oxidation products. Analyt. Chem. 54: 174-178

Hedges, J. I., Ertel, J. R., Quay, P. D., Grootes, P. M., Richey, J. E., Devol, A. H., Farwell, G. W., Schmidt, F. W. Salati, E. (1986). Organic carbon-14 in the Amazon River system. Science 231. 1129-1131

Hessen, D. O.. Anderson, T., Lyche, A. (1990). Carbon metabolism in a humic lake: pool sizes and cycling through zooplankton. Limnol. Oceanogr. 35: 84-99

Jones, R. I. (1992). The influence of humic substances on lacustrine planktonic food chains. Hydrobiologia 229: 73-91

Kieber, D. J., McDaniel, J., Mopper, K. (1989). Photochemical source of biological substrates in sea water: implications for carbon cycling. Nature 341: 637-639

Kieber, R. J., Zhou, X., Mopper, K. (1990). Formation of carbonyl compounds from UV-induced photodegradation of humic substances in natural waters: fate of riverine carbon in the sea. Limnol. Oceanogr. 35: 1503-1515

Leff, L. G., Meyer, J. L. (1991). Biological availability of dissolved organic carbon along the Ogeechee River continuum. Limnol. Oceanogr. 36: 315-323

Mantoura, R. F. C., Woodward, E. M. S. (1983). Conservative behavior of riverine dissolved organic carbon in the Severn Estuary: chemical and geological implications. Geochim. cosmochim. Acta 47: 1293-1309

Meybeck, M. (1982). Carbon, nitrogen, and phosphorus transport by world rivers. Am. J. Sci. 282: 401-450

Meyer, J. L., Edwards, R. T., Risley, R. (1987). Bacterial growth on dissolved organic carbon from a blackwater river. Microb. Ecol. 13: 13-29

Meyers-Schulte, K. J., Hedges, J. I. (1986). Molecular evidence for a terrestrial component of organic matter dissolved in ocean water. Nature 321: 61-63

Mopper, K., Zhou, X., Kieber, R. J., Kieber, D. J., Sikorski, R. J., Jones, R. D. (1991). Photochemical degradation of dissolved organic carbon and its impact on the oceanic carbon cycle. Nature 353: 60-62

Moran, M. A., Hodson, R. E. (1989). Formation and bacterial utilization of dissolved organic carbon derived from detrital lignocellulose. Limnol. Oceanogr. 34: 1034-1047

Moran, M. A., Hodson, R. E. (1990). Bacterial production on humic and nonhumic components of dissolved organic carbon. Limnol. Oceanogr. 35: 1744-1756

Moran, M. A., Hodson, R. E. (1994). Dissolved humic substances of vascular plant origin in a coastal marine environment. Limnol. Oceanogr. (in press)

Moran, M. A., Pomeroy, L. R., Sheppard, E. S., Atkinson, L. P., Hodson, R. E. (1991a). Distribution of terrestrially-derived dissolved organic matter on the southeastern U.S. continental shelf. Limnol. Oceanogr. 36: 1134-1149

Moran, M. A., Wicks, R. J., Hodson, R. E. (1991b). Export of dissolved organic matter from a mangrove swamp ecosystem: evidence from natural fluorescence, dissolved lignin phenols, and bacterial secondary production. Mar. Ecol. Prog. Ser. 76: 175-184

Thurman, E. M. (1985). Organic geochemistry of natural waters. Nijhoff/Junk, Dordrecht

Tranvik, L. J., Höfle, M. G. (1987). Bacterial growth in mixed cultures on dissolved organic carbon from humic and clear waters. Appl environ. Microbiol. 53: 482-488

Williams, P. M., Gordon, L. I. (1970). Carbon-13:carbon-12 ratios in dissolved and particulate organic matter in the sea. Deep Sea Res. 17: 19-27 